\title{
A Rare Cause of Reversible Splenial Lesion Syndrome (RESLES): Benign Convulsions with Mild Gastroenteritis
}

\author{
(D) Nida Uysal1, (1) Afshin Dezhakam², (D) Seda Kanmaz², (1) Sanem Yılmaz² \\ ${ }^{1}$ Ege University Faculty of Medicine, Department of Pediatrics, İzmir, Turkey \\ 2Ege University Faculty of Medicine, Department of Pediatrics, Clinic of Child Neurology, İzmir, Turkey
}

\begin{abstract}
Transient lesions involving the splenium of corpus callosum is defined as reversible splenial lesion syndrome (RESLES). Benign convulsions with mild gastroenteritis is a rare condition which may be associated with RESLES. Since the prognosis is excellent, the awareness of this association is important to prevent unnecessary investigations and anti-epileptic drug therapy.
\end{abstract}

Keywords: Splenium, corpus callosum, gastroenteritis, seizure, RESLES

\section{Introduction}

Reversible splenial lesion syndrome (RESLES) is a rare clinico-radiological entity characterized by a transient lesion in the splenium of corpus callosum (1). RESLES may result from various causes such as infections, metabolic derangements, high-altitude cerebral edema, seizures or antiepileptic drug withdrawal. In the paediatric population, the most common form of RESLES is mild encephalitis/ encephalopathy with a reversible splenial lesion (MERS) which may occur during infectious diseases (2). In MERS, encephalopathy lasts longer than 12 hours and no evidence of inflammation is found in the cerebrospinal fluid. Disturbance of consciousness lasting less than 12 hours or an absence of altered mental status during the clinical course is defined as non-MERS form of RESLES (1).
Benign convulsions with mild gastroenteritis (CwG) was first described by Mooroka in 1982. It is characterized by; (1) occurrence in previously healthy infants or young children aged between 6 months and 3 years; (2) afebrile generalized convulsions sometimes seen in clusters related to gastroenteritis without moderate to severe dehydration; (3) normal laboratory examination including electrolytes, blood glucose and cerebrospinal fluid; (4) normal interictal electroencephalography (EEC); and (5) excellent seizure and developmental outcomes (3). Rotavirus, norovirus and other round-shaped viruses are the most common causative agents related to this entity (4).

\section{Case Report}

A previously healthy 42-month-old girl with diarrhoea and vomiting for two days was admitted to our hospital 
due to a brief afebrile generalized tonic-clonic seizure. Her past medical history and family history were unremarkable. On admission, she was alert and had normal physical and neurological examination. During the emergency room follow-up, she had another afebrile generalized tonic-clonic seizure with a duration of 3 minutes and rapidly regained consciousness. Laboratory studies including hemogram, liver and kidney function tests, uric acid, serum electrolytes and acute phase reactants were normal. Stool sample analysis revealed no pathogens. EEG was found to be normal. Cranial magnetic resonance imaging (MRI) revealed increased T2-signal intensity in the splenium of corpus callosum and hypo-intense signal on apparent diffusion coefficient images (Figure 1). She had no further seizures and was discharged on the third day of hospitalization with no antiepileptic drug treatment. The follow-up cranial MRI of the patient performed after 4 weeks showed complete resolution of the lesion (Figure 2). The patient is now seizure free for 6 months with a normal neurological examination and developmental milestones.

\section{Discussion}

In 2007, Natsume et al. (5) first described the association of RESLES and CWG in two paediatric cases. After this initial

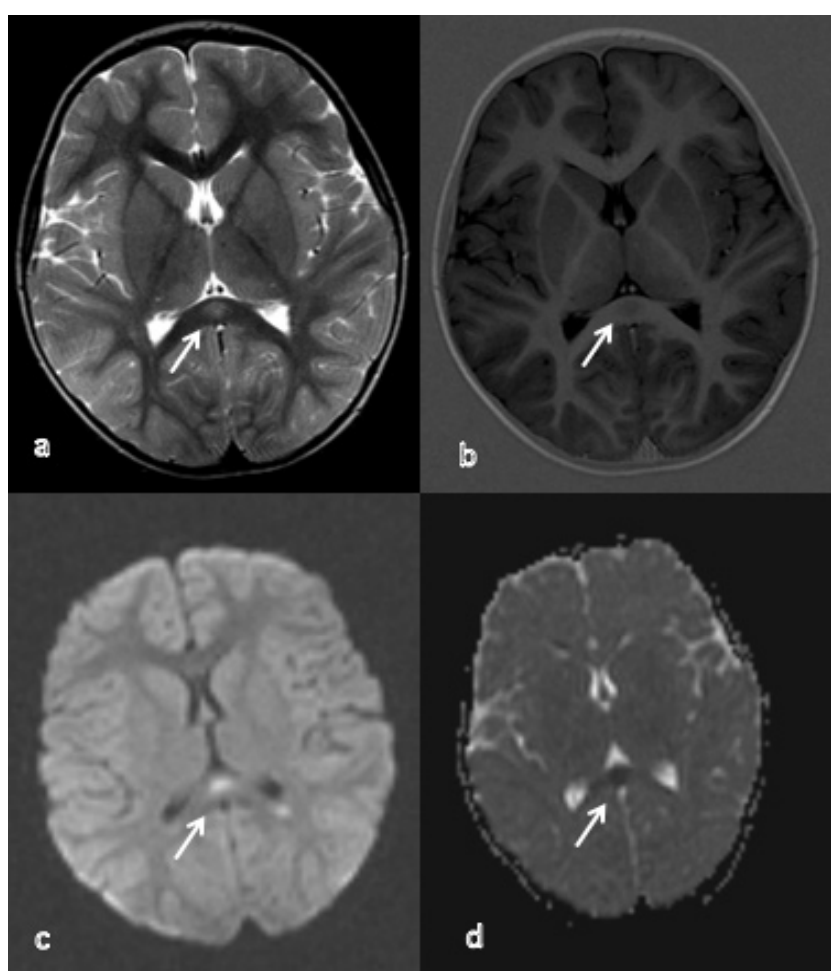

Figure 1. Cranial magnetic resonance images on admission demonstrating a splenial lesion of the corpus callosum. Axial T1weighted (a), axial T2-weighted (b), diffusion-weighted (c), and the corresponding apparent diffusion coefficient map (d) description, a few cases of different ethnic origins, mainly from Asia, were published (6-8) (Table I). In a multicentre study conducted by the Tokai Pediatric Neurology Society, the frequency of RESLES in CwG was presented as being $22 \%$ (9). Kato et al. (8) reported nine Japanese cases with a transient splenial lesion of corpus callosum occurring during rotavirus gastroenteritis. While eight of these cases presented with encephalopathy, and were classified as MERS, only one case had clinical features consistent with the non-MERS form of RESLES due to CWG. In another study among 233 patients with RESLES, five patients with no clinical manifestations of encephalitis such as delirium or an altered level of consciousness were diagnosed with RESLES secondary to CwG. Acute seizure treatment with anticonvulsive drugs such as diazepam or phenobarbital, anti-viral agents and rehydration was administrated if necessary in the acute period, but no long-term antiepileptic treatment was given (7). Similar to these cases in the literature, the present case had only two brief generalized seizures without any encephalopathic features during a gastrointestinal infection. Although there is no specific laboratory finding for the diagnosis of CwG, Yoo et al. (10) found that serum uric acid levels are significantly higher in CwG patients than in patients with acute gastroenteritis and febrile seizures. However, the uric acid level of the present case was found to be within the normal range. The presence of a splenial lesion detected on the cranial MRI performed for the recurrent afebrile seizures led to the diagnosis of non-MERS form of RESLES secondary to CWG. No long-term antiepileptic therapy was given. The complete resolution of the splenial lesion as seen in the follow-up MRI, normal neurological development and the absence of recurrent afebrile seizures confirmed the diagnosis.

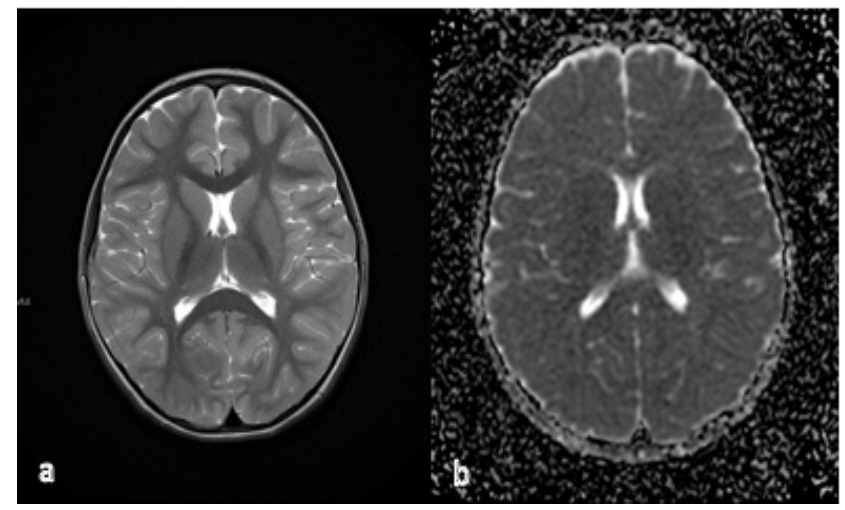

Figure 2. Follow-up cranial magnetic resonance images demonstrating the resolution of the splenial lesion. Axial T2-weighted (a) and apparent diffusion coefficient map (b) 


\begin{tabular}{|c|c|c|c|c|c|c|c|}
\hline Publication & $\begin{array}{l}\text { Number of } \\
\text { patients }\end{array}$ & $\begin{array}{l}\text { Age- } \\
\text { months }\end{array}$ & Symptoms & Etiology & EEG & Treatment & $\begin{array}{l}\text { Day of normal } \\
\text { follow-up } \\
\text { MRI/Outcome }\end{array}$ \\
\hline $\begin{array}{l}\text { Natsume et al. } \\
\text { (5) } \\
2007\end{array}$ & 2 & $\begin{array}{l}24 \\
36\end{array}$ & $\begin{array}{l}5 \text { episodes of focal } \\
\text { seizures } \\
2 \text { episodes of } \\
\text { generalized seizures }\end{array}$ & Rotavirus & Normal & $\begin{array}{l}\text { Diazepam, } \\
\text { phenobarbital } \\
\text { - }\end{array}$ & $\begin{array}{l}\text { 9/good } \\
21 / \text { good }\end{array}$ \\
\hline $\begin{array}{l}\text { Kato et al. } \\
\text { (8) } 2009\end{array}$ & 1 & 12 & $\begin{array}{l}3 \text { episodes of tonic } \\
\text { seizures }\end{array}$ & Rotavirus & $\begin{array}{l}\text { Intermittent spikes, } \\
\text { occipital slow wave }\end{array}$ & Diazepam & 6/good \\
\hline $\begin{array}{l}\text { Jang and Lee } \\
\text { (6)2010 }\end{array}$ & 1 & 30 & $\begin{array}{l}2 \text { episodes of } \\
\text { generalized tonic-clonic } \\
\text { seizures }\end{array}$ & Rotavirus & Normal & $\begin{array}{l}\text { Rehydration, } \\
\text { empiric antibiotics } \\
\text { and acyclovir }\end{array}$ & 6/good \\
\hline $\begin{array}{l}\text { Jiang et al. } \\
\text { (7) } 2014\end{array}$ & 5 & $\begin{array}{l}36 \\
14 \\
28 \\
30 \\
24\end{array}$ & $\begin{array}{l}4 \text { episodes of } \\
\text { generalized tonic-clonic } \\
\text { seizures } \\
3 \text { episodes of } \\
\text { generalized tonic-clonic } \\
\text { seizures } \\
5 \text { episodes of } \\
\text { generalized tonic-clonic } \\
\text { seizures } \\
2 \text { episodes of } \\
\text { generalized tonic-clonic } \\
\text { seizures } \\
4 \text { episodes of } \\
\text { generalized tonic-clonic } \\
\text { seizures }\end{array}$ & $\begin{array}{l}- \\
- \\
- \\
- \\
\text { Rotavirus }\end{array}$ & $\begin{array}{l}\text { Normal } \\
\text { Normal } \\
\text { Normal } \\
\text { Normal } \\
\text { Occipital slow } \\
\text { wave }\end{array}$ & $\begin{array}{l}\text { Rehydration, } \\
\text { ribavirin, } \\
\text { diazepam } \\
\text { Rehydration, } \\
\text { ribavirin, } \\
\text { phenobarbital } \\
\text { Rehydration, } \\
\text { ribavirin, } \\
\text { phenobarbital } \\
\text { Rehydration, } \\
\text { ribavirin, } \\
\text { diazepam } \\
\text { Rehydration, } \\
\text { ribavirin, } \\
\text { diazepam, } \\
\text { phenobarbital }\end{array}$ & $\begin{array}{l}11 / \text { good } \\
10 / \text { good } \\
15 / \text { good } \\
10 / \text { good } \\
12 / \text { good }\end{array}$ \\
\hline Presented case & 1 & 42 & $\begin{array}{l}2 \text { episodes of } \\
\text { generalized tonic-clonic } \\
\text { seizures }\end{array}$ & - & Normal & Rehydration & $30 /$ good \\
\hline
\end{tabular}

\section{Conclusion}

In young children with recurrent afebrile seizures and gastroenteritis without fever, dehydration and ion imbalance, the association of RESLES and CWG should be kept in mind. Since the prognosis is excellent with no permanent neurological sequelae, awareness of this rare clinico-radiological entity is important in order to avoid unnecessary investigations and long term anti-epileptic drug therapy.

\section{Ethics}

Informed Consent: The consent form was received from the parents of the patient.

Peer-review: Externally peer-reviewed.

\section{Authorship Contributions}

Concept: N.U., A.D., S.K., S.Y., Design: N.U., A.D., S.K., S.Y., Data Collection or Processing: N.U., A.D., S.K., S.Y.,
Analysis or Interpretation: N.U., A.D., S.K., S.Y., Literature Search: N.U., A.D., S.K., S.Y., Writing: N.U., A.D., S.K., S.Y.

Conflict of Interest: No conflict of interest was declared by the authors.

Financial Disclosure: The authors declared that this study received no financial support.

\section{References}

1. Kashiwagi M, Tanabe T, Shimakawa S, et al. Clinico-radiological spectrum of reversible splenial lesions in children. Brain Dev 2014; 36:330-6.

2. Tada H, Takanashi J, Barkovich Al, et al. Clinically mild encephalitis/encephalopathy with a reversible splenial lesion. Neurology 2004; 63:1854-8.

3. Kang B, Kwon YS. Benign convulsion with mild gastroenteritis. Korean / Pediatr 2014; 57:304-9.

4. Kawano G, Oshige K, Syutou S, et al. Benign infantile convulsions associated with mild gastroenteritis: A retrospective study of 39 cases including virological tests and efficacy of anticonvulsants. Brain Dev 2007; 29:617-22. 
5. Natsume J, Naiki M, Yokotsuka T, et al. Transient splenial lesions in children with "benign convulsions with gastroenteritis." Brain Dev 2007; 29:519-21.

6. Jang YY, Lee KH. Transient splenial lesion of the corpus callosum in a case of benign convulsion associated with rotaviral gastroenteritis. Korean J Pediatr 2010; 53:859-62.

7. Jiang L, Mao S, Xu J, Gao F. Reversible splenial lesion syndrome in children with benign convulsions associated with mild gastroenteritis: A retrospective study of five cases. Brain Dev 2019; 41:271-5.
8. Kato $\mathrm{Z}$, Orii $\mathrm{KE}$, Morimoto $\mathrm{M}$, et al. A Transient lesion in the corpus callosum during rotavirus infection. Pediatr Neurol 2009; 41:467-9.

9. Ogawa $\mathrm{C}$, Kidokoro $\mathrm{H}$, Ishihara $\mathrm{N}$, et al. Splenial Lesions in Benign Convulsions With Gastroenteritis Associated With Rotavirus Infection. Pediatr Neurol 2020; 109:79-84.

10. Yoo $\mathrm{H}, \mathrm{Kim} \mathrm{W}, \mathrm{Cho}$ ), et al. Elevated serum uric acid in benign convulsions with mild gastroenteritis in children. J Clin Neurol 2019; 15:496-501. 